\title{
PELATIHAN HIDROCHILI (TANAMAN CABAI SECARA HIDROPONIK) PADA KELUARGA PENERIMA MANFAAT DESA PRAMBONWETAN KECAMATAN RENGEL - TUBAN
}

\author{
Saeful Mizan \\ Universitas PGRI Ronggolawe Tuban, email: $\underline{\text { miz_zhan@yahoo.com }}$ \\ Sri Cacik \\ Universitas PGRI Ronggolawe Tuban, email: sricacik.mpd@ gmail.com
}

\begin{abstract}
Abstrak
Sebagian besar KPM di desa Prambonwetan kecamatan Rengel kabupaten Tuban ini telah memiliki usaha di bidang pertanian dengan memanfaatkan tanah negara yang ada di pinggir sungai Bengawan Solo. Salah satu jenis tanaman yang di tanam adalah cabai. Kendala utama yang dihadapi adalah keterbatasan lahan, serangan hama, bergantung pada musim. Guna mengatasi kendala tersebut maka perlu diberikan pengetahuan dan keterampilan tentang sistem tanam cabai yang dikembangkan adalah sistem tanam cabai dengan media air atau disebut sistem hidroponik. Diharapkan melalui kegiatan pelatihan hidrochili (tanam cabai secara hidroponik), KPM dapat menerapkan tanam cabai secara hidroponik sehingga dalam jangka panjang dapat meningkatkan taraf perekonomian KPM. Metode yang dilakukan untuk mencapai tujuan dari pengabdian masyarakat ini meliputi dua tahap, yaitu tahap persiapan dan pelaksanaan. Pada tahap persiapan, tim pengabdian masyarakat melakukan surve, penentuan lokasi dan sasaran, persiapan dan penyusunan materi pelatihan, persiapan alat dan bahan untuk tahap pelaksanaan pelatihan. Tahap pelaksanaan meliputi penyuluhan terkait hidrochili, demonstrasi hidrochili, dan pendampingan kepada KPM dalam melakukan hidrochili. Kegiatan pendampingan dilakukan oleh tim pelaksana sampai KPM dapat melaksanakan sistem tanam cabai secara hidroponik. Hasil pelatihan menunjukkan bahwa, KPM yang mampu melaksanakan tanam cabai secara hidroponik. Berdasarkan angket respon yang diberikan kepada KPM diketahui bahwa rata-rata keseluruhan $88 \%$. Hal tersebut menunjukkan respon positif terhadap pelatihan hidrochili.
\end{abstract}

Kata Kunci: Hidrochili, KPM, cabai.

\section{Abstract}

Most of the KPM in Prambonwetan village, Rengel sub-district, Tuban, have had business in agriculture by utilizing state land on the banks of the Bengawan Solo river. One type of plant that is planted is chili. The main obstacles faced are limited land, pest attacks, depending on the season. In order to overcome these obstacles, it is necessary to provide knowledge and skills about the chili planting system that is developed is a chili planting system with water media or called a hydroponic system. It is expected that through hydrochemical training activities (hydroponic chili planting), KPM can apply chili cultivation hydroponically so that in the long run it can improve the economy level of KPM. The method used to achieve the goals of community service includes two stages, namely the preparation and implementation stages. In the preparation stage, the community service team conducts surveys, determines locations and targets, prepares and prepares training materials, prepares tools and materials for the training phase. The implementation phase includes hydrochili related counseling, hydrochili demonstration, and assistance to KPM in carrying out hydrochili. Mentoring activities are carried out by the implementation team until KPM can implement the chili cultivation system hydroponically. The training results show that KPM is capable of hydroponic chili cultivation. Based on the response questionnaire given to KPM it was found that the overall average was $88 \%$. This shows a positive response to hydrochiliary training.

Keywords: Hydrochili, KPM, chili. 


\section{PENDAHULUAN}

Latar belakang yang mendasari kegiatan pengabdian masyarakat ini adalah keluarga penerima manfaat (KPM) sebagai mitra memiliki permasalahan di bidang perekonomian. KPM merupakan sebuah keluarga yang berdasarkan data kementerian sosial berhak menerima bantuan berupa uang dari pemerintah. Berdasarkan data tersebut maka KPM dapat dikatakan memiliki tingkat perekonomian yang berkategori rendah. KPM yang menjadi mitra berada di desa Prambonwetan kecamatan Rengel kabupaten Tuban. Sebagian besar KPM ini telah memiliki usaha di bidang pertanian dengan memanfaatkan tanah negara yang ada di pinggir sungai Bengawan Solo. Beberapa jenis tanaman yang ditanam adalah ketela rambat, singkong, cabai, tomat, dll. Pertanian tersebut memiliki kendala antara lain serangan hama, bergantung pada musim, keterbatasan lahan, dan bencana alam. Jenis pertanian KPM yang harga jualnya lebih potensial adalah cabai. Akan tetapi pertanian yang dilakukan oleh KPM memiliki beberapa kendala. Ketersedian lahan yang tidak cukup luas menyebabkan KPM tidak dapat mengembangkan pertanian cabai. Serangan hama juga sering menyebabkan gagal panen cabai. Terjadinya bencana banjir yang disebabkan oleh luapan sungai Bengawan Solo dapat menghanyutkan tanaman cabai. Budi daya cabai memang menjanjikan keuntungan yang menarik, tetapi tidak jarang petani cabai mengalami kerugian yang disebabkan harga cabai tidak stabil. Pada saat petani cabai mengalami gagal panen, harga cabai bisa mencapai $\mathrm{Rp}$. 200.000,00 akan tetapi pada musim panen raya cabai harga cabai bisa di bawah Rp. 10.000,00. Cabai merupakan hasil panen yang tidak dapat disimpan terlalu lama, sehingga petani cabai tidak dapat menimbun cabai untuk menunggu kenaikan harga.

Berdasarkan permasalahan dan keuntungan sistem tanam hidroponik, maka tim pengabdian masyarakat Universitas PGRI Ronggolawe Tuban ingin melaksanakan pelatihan hidrochili (tanam cabai secara hidroponik) pada KPM (Keluarga Penerima Manfaat) desa Prambonwetan kecamatan Rengel kabupaten Tuban.

Kegiatan ini bertujuan untuk memberikan pengetahuan dan keterampilan tentang sistem tanam cabai kepada KPM yang ada di desa Prambonwetan kecamatan Rengel kabupaten Tuban. Sistem tanam cabai yang dikembangkan adalah sistem tanam 
cabai dengan media air atau disebut sistem hidroponik. Kelebihan dari sistem tanam cabai hidroponik adalah tidak bergantung pada musim, tidak bergantung pada ketersediaan lahan, dapat meminimalisir serangan hama dan bencana. Diharapkan melalui kegiatan pelatihan hidrochili (tanam cabai secara hidroponik), KPM dapat meningkatkan penghasilnya sehingga taraf perekonomian dapat ditingkatkan.

Lahan pekarangan sekitar rumah KPM dapat digunakan untuk budidaya cabai sebagai salah satu cara untuk meningkat perekonomian KPM. Akan tetapi diperlukan sebuah inovasi budidaya cabai yang lebih efektif dan efisien. Sistem yang dipilih oleh tim pelaksana pengabdian masyarakat adalah hidroponik. Menurut Tallel, dkk. (2017:3), hidroponik adalah budidaya tanaman tanpa tanah sehingga tanaman hidroponik ditanam dengan pemanfaatan air sebagai media tanam. Keuntungan sistem hidroponik adalah (1) kebersihan tanaman untuk tumbuh dan berproduksi lebih terjamin, (2) perawatan lebih praktis dan gangguan hama lebih terkontrol, (3) pemakaian pupuk lebih hemat, (4) tanaman yang mati lebih mudah diganti dengan tanaman baru, (5) tidak membutuhkan banyak tenaga kasar karena metode kerja lebih hemat dan memiliki standarisasi, (6) tanaman dapat tumbuh lebih pesat dan dengan keadaan yang tidak kotor dan rusak, (7) hasil produksi lebih kontinu dan lebih tinggi dibandingkan dengan penanaman di tanah, (8) harga jual hidroponik lebih tinggi dari produk non-hidroponik, (9) beberapa jenis tanaman dapat dibudidayakan di luar musim, (10) tidak ada resiko kebanjiran, erosi, kekeringan, atau ketergantungan dengan kondisi alam, (11) tanaman hidroponik dapat dilakukan pada lahan atau ruang yang terbatas (Roidah, 2014:44).

\section{METODE}

Tahapan pelatihan yang dilakukan adalah: Tahap persiapan yang meliputi: a) Survei ke beberapa KPM yang bermata pencaharian sebagai petani cabai untuk mengetahui permasalahanpermasalahan yang dialami oleh KPM terkait penanaman cabai. b) Penentuan lokasi dan sasaran berdasarkan hasil survei c) Penyusunan materi pelatihan, yang meliputi: brosur yang berisi petunjuk hidrochili dan slide power point untuk kegiatan pelatihan hidrochili. d) Mempersiapkan alat dan bahan yang diperlukan untuk mendemonstrasikan cara menanam cabai dengan sistem hidroponik. Selanjutnya tahap 
pelaksanaan meliputi : a) Penjelasan tentang sistem hidroponik. b) Penjelasan tentang kelebihan sistem hidroponik. c) Penjelasan tentang cara melakukan hidroponik cabai. d) Mendemonstrasikan cara menanam cabai dengan sistem hidroponik. e) Membimbing mitra dalam menanam cabai dengan sistem hidroponik. f) Mengevaluasi cabai yang ditanam mitra dengan sistem hidroponik hingga dihasilkan cabai sebagai produk. Evaluasi dilakukan dengan menggunakan angket respon KPM

\section{HASIL}

Hasil Pelatihan Hidrochili pada KPM desa Prambonwetan kecamatan Rengel kabupaten Tuban.

1. Masyarakat KPM mampu melaksanakan penanaman secara hodroponik

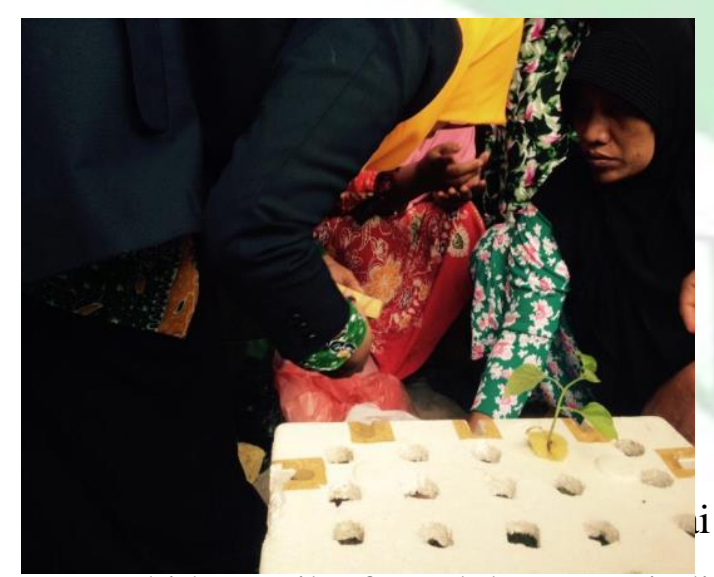

secara hidroponik, foto dokumentasi di atas menunjukkan bahwa cabai yang ditanaman sudah mulai tumbuh kurang lebih $5 \mathrm{~cm}$.
2. Respon Positif setelah melaksanan penanam cabai. Hasil monitoring dan evaluasi yang dilakukan setelah satu bulan penanam cabai menununjukkan hasil sebagai berikut.

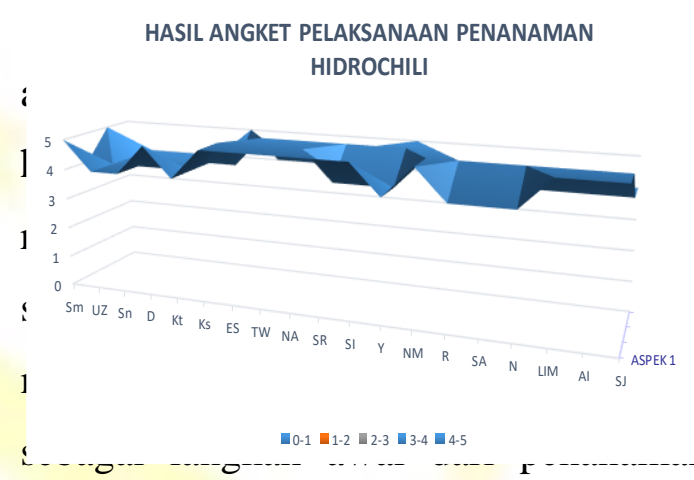

memperoleh presentase sebanyak $93 \%$. Pada aspek ke-2 : mampu memcampurkan nutrisi untuk kebutuhan pokok tanaman cabai memperoleh presentase sebanyak 92\%. Pada aspek ke-3: penanaman dilakukan sesuai dengan langkah-langkah pelatihan hidrochili memperoleh presentase sebanyak $88 \%$. Pada aspek ke-4: cabai yang ditanam mulai tumbuh dengan baik mendapatkan presentase sebanyak $80 \%$. Dengan rata-rata keseluruhan $88 \%$ dapat dikatakan bahwa penanaman cabai secara hidroponik yang dilakukan sangat berhasil.

\section{PEMBAHASAN}

Hasil kegiatan pelatihan hidrochili anggota KPM (Keluarga Penerima Manfaat) desa Prambonwetan kecamatan Rengel-Tuban Masyarakat KPM dalam 
segi keterampilan mampu melaksanakan penanaman secara hidroponik. Selama proses penanaman masyarakat KPM juga memberikan respon yang positif dibuktikan dari hasil angket dengan 4 indikator dimana rata-rata mendapatkan kurang lebih 88\%. Hal tersebut menunjukkan masyarakat menguasai secara teori dan praktek tentang sistem hidroponik teersebut. Hal ini juga terlihat dari selama proses penanaman bibit pada media sampai pemanenan kurang lebih berlangsung selama 9 minggu dan setiap 7-8 hari biasanya memanen kembali.

\section{KESIMPULAN}

KPM (Keluarga Penerima Manfaat) yang terdapat di desa Prambonwetan kecamatan Rengel kabupaten Tuban memperoleh pengetahuan terkait pelatihan hidrochili (tanam cabai secara hidroponik) melalui kegiatan sosialisasi diikuti dengan seluruh kelompok KPM (Keluarga Penerima Manfaat) dengan sangat antusias terlihat dari Kelompok KPM mampu membuat sistem tanam cabai secara hidroponik yang belum pernah mereka dapatkan sebelumnya. Kegiatan praktek membuat sistem tanam cabai secara hidroponik melalui metode demonstrasi oleh beberapa anggota Pengmas dan selanjutnya diikuti oleh perwakilan kelompok KPM (Keluarga Penerima Manfaat) Annisa dan Reni Secara berkelanjutan, hasil yang mereka peroleh secara skala kecil digunakan untuk memenuhi kehidupan sehari-hari dan dalam skala luas mereka melakukan penjualan sehingga dapat meningkatkan perekonomian.

\section{REFERENSI}

Roidah, I. S., dkk. 2014. Pemanfaatan Lahan dengan Menggunakan Sistem Hidroponik. Tulungagung: Jurnal Universitas Tulungagung Bonorowo.

Tallel, T. E., dkk. 2017. Hidroponik untuk Pemula. Manado: LPPM UNSRAT.

Setiawan, Hendra. 2017. Kiat Sukses Budidaya Cabai Hidroponik. Depok: Bio Genesis PT. Huta Parhapuran

Purnomo , Djoko, Dwi Harjoko dan Trijono Djoko Sulistyo. 2018. Budidaya Cabai Rawit Sistem Hidroponik Substrat Dengan Variasi Media dan Nutrisi https://jurnal.uns.ac.id/carakatani/artic le/view/11996 (online) diakses 29 Januari 2018 